\section{Scientific journal}

PHYSICAL AND MATHEMATICAL EDUCATION

Has been issued since 2013.

Науковий журнал

ФІЗИКО-МАТЕМАТИЧНА ОСВІТА

Видається з 2013.
ISSN 2413-158X (online)

ISSN 2413-1571 (print)

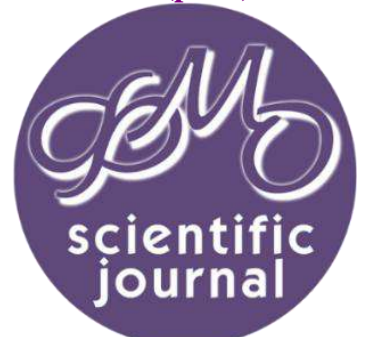

Семенець Д.А., Соя О.М., Тютюн Л.А. Використання електронного освітнього контенту в закладах вищої освіти Фізико-математична освіта. 2020. Випуск 1(23). Частина 2. С. 6-11.

Semenets D., Soia O., Tyutyun L. Using of electronic educational content in higher education institutions. Physical and Mathematical Education. 2020. Issue 1(23). Part 2. P. 6-11.

DOI 10.31110/2413-1571-2020-023-1-2-001

UDC 378.147.091.33:004.77

Dmytro Semenets

Vinnytsia Mykhailo Kotsiubynskyi State Pedagogical University, Ukraine dmisem@yahoo.com ORCID: 0000-0002-8640-3649

Olena Soia

Vinnytsia Mykhailo Kotsiubynskyi State Pedagogical University, Ukraine soya.o.m@gmail.com ORCID: 0000-0002-0937-299X

Lyubov Tyutyun

Vinnytsia Mykhailo Kotsiubynskyi State Pedagogical University, Ukraine lyubov.tyutyun@gmail.com ORCID: 0000-0001-9466-874

\title{
USING OF ELECTRONIC EDUCATIONAL CONTENT IN HIGHER EDUCATION INSTITUTIONS
}

ABSTRACT

Formulation of the problem. In modern conditions, it is relevant to study the feasibility and methodological principles of integrated usage of electronic educational content in higher education institutions and to identify features of its functioning. It is shown that an innovative approach to the introduction of digital technologies of education in modern institutions of higher education has significantly changed the educational space and allows to solve a number of important didactic problems. In particular, the use of the virtual learning environment provides great opportunities for student mobility in learning, takes into account their personal needs and preferences, allows the student to choose a convenient time and place for studying, work on an individual schedule, to schedule work, build their own educational trajectory and more.

Materials and Methods. We have analyzed the researches of modern scientists and methodologists, monitored the websites of foreign and Ukrainian universities, used our own pedagogical experience.

Results. It is substantiated that the creation and use of electronic educational content in higher education institutions ensure: realization of the principles of individualization, consciousness, and activity, visualization, accessibility of learning; acquisition of competencies in the use of software to solve professional problems. The example of the creation of the project "Personal site of the lecturer» with the appropriate teaching and methodological content. The researches of modern up-to-date technologies allowing to create Web-sites and Web-portals are carried out, the means of Web-sites' development are considered and classified by their complexity. Student Web-cabinets have been shown using well-known databases and high-level software platforms.

Conclusions. We should not exaggerate the possibilities of Web-portals, because their creation requires the correct selection of learning content in accordance with the didactic properties and capabilities of digital learning technologies, forecasting the possible impact on the nature of thinking and behavior of participants in the educational process.

KEY WORDS: virtual learning environment, information and communication technologies, e-learning, higher education institutions, specialist training, Web site, Web-portal.

\section{INTRODUCTION}

Formulation of the problem. The current stage of society development is considered in the context of broad informatization of all its spheres. Up-to-date and reliable information is the main source and resource of personal development. And the acceleration of the growth of information and free access to it has a positive effect on the emergence of a high-tech market for information products and services, the expansion of the using limits of computer information technology in all areas of human activity, changing the way of life, including education.

In the National Strategy for the Development of Education in Ukraine for the period up to 2021 among the strategic directions of public education policy is to ensure its accessibility and continuity throughout life; development of scientific and 
innovative activity in education, improving the quality of education on an innovative basis; informatization of education, improvement of library and information resources of education and science, and among the main tasks - ensuring systematic improvement of the quality of education on an innovative basis, modern psychological-pedagogical and scientific-methodological support of the educational process; ensuring of the creation of conditions for the development of the modern means of education (educational-methodical, electronic, technical, information-communication, etc.).

Currently, higher education institutions in Ukraine have gained broad authority over the principles of their activities. According to the Law of Ukraine "On Higher Education», they were granted the rights that constitute the content of their autonomy and self-government, in particular, «to develop and implement educational (scientific) programs within the licensed specialty; ... independently develop and implement their own programs of educational, artistic, scientific, scientific-technical and innovative activity; independently introduce specializations, determine their content and curricula» etc.

Therefore, scientific and pedagogical staff of the higher education institutions have the opportunity to determine the priorities in scientific, educational and research activities, to choose the best software tools, to develop and implement innovative technologies and methods in the educational process within the approved curricula for training specialists.

According to the National Strategy for the Development of Education in Ukraine until 2021, «the priority of educational development is the implementation of modern informational and communicational technologies that ensure the improvement of the educational process, accessibility and efficiency of education, preparation of the young generation for life in the information society».

The contradictions between the expediency of using virtual learning environments in higher education institutions and the lack of scientifically grounded methods of their application, the need to form competence in the useing of virtual learning environments in the teaching of future teachers of mathematics, physics and informatics on one hand and the lack of effective models of their implementation on the other hand outline the problem of investigating the functioning of virtual learning environments in pedagogical higher education institutions.

An analysis of recent research. In the research we relied on scientific works about informative and innovative technologies in modern education (Gurevich, Kozyar, Kademiya\&Shevchenko, 2015; Gurevich, Kademiya\&Kozyar, 2012), methodological approaches to the development of education in the conditions of information society (Lazarenko, Kolomiyets\&Klimenko, 2017), the main directions of formation of educational environment by means of informative and communicative technologies and its influence on natural-mathematical and technical education (Velichko, 2008), formation of innovative environment of students of physical and mathematical specialties (Kovtonyuk\&Dydovyk, 2018), providing of E-learning using a personal teacher's website (Tyutyun\&Soia, 2018).

At the same time, it has been found out that the problems and prospects of development and integration of informative and computer technologies, Internet technologies and telecommunications in the educational process of higher education institutions are receiving considerable attention in the scientific and pedagogical literature, while the introduction of virtual educational environments is a problem which is insufficiently investigated. Unsolved problems are the scientific substantiation of the principles of creation and supporting systems of the virtual educational environment in the higher education institutions in general, and especially of the environment that contributes to the formation and development of natural and mathematical education, which is the key to the knowledge of the world, the basis of scientific and technological progress and which takes the priority positions in professions, including those ones which are related to the natural sciences, technology and computer technology, economics, etc. All the above identified the relevance of the problem under study and the choice of topic of the proposed article.

The goal of the article. To substantiate the feasibility and methodological foundations of integrated implementation of the virtual learning environment in higher education institutions and to identify the peculiarities of its functioning in the context of continuous education.

\section{RESEARCH METHODS}

Analysis of research by scientists and methodologists, analysis of pedagogical experience, review of Web sites of foreign and Ukrainian universities.

\section{RESEARCH RESULT}

An innovative approach to the implementation of informative and communicative technologies (ICT) of education in modern higher education institution has significantly changed the educational space and it allows to solve a number of didactic problems. Computer technology not only help to organize the learning process, but they also constantly analyze its feedback, which has a positive effect on student learning results.

Acting as an integrating factor, ICTs must first be aimed to helping students to transfer knowledge and skills from one field to another, from familiar conditions to unfamiliar situations.

An electronic way of obtaining educational information is a common norm in organizing educational activities for the modern generation of students. In our opinion, e-learning is one of the possible tools that provides virtually unlimited possibilities for placement, storage, regeneration, processing and delivery of information of any volume and content at any distance. These processes are extremely important for the current higher education student in the face of rapid changes in the educational environment.

E-learning allows to combine different means, forms and methods of interaction of the teacher with students, provides mobility of future teachers of mathematics, physics and informatics in training, provides realization of principles of individualization, consciousness and activity, visualization, accessibility studying, acquisition of competencies for the use of program means for professional solutions tasks. Creation of electronic educational resources with active use of modern opportunities of innovative technologies stimulates independent educational and cognitive activity of students, provides transition to self-education and distance learning, activates use of search and research methods in higher education institutions (Tyutyun\&Soia, 2018). 
E-learning provides great opportunities for students' mobility in learning, taking into account their personal needs and preferences. Using electronic content allows the student to choose a convenient time and place for study, work on an individual schedule, plan work schedules, build their own educational trajectory.

Experience shows that the problem of the formation of professional competence of future teachers of mathematics, physics and computer science is closely related to the formation of their instrumental competence. It is about becoming independent and responsible members of modern society, able to interact in solving social, industrial and economic problems, who have the skills of independent work in educational, scientific and professional activity, ready for self-improvement, able to take responsibility, find constructive sound solutions to problem situations, who have a high professional level and practical computer and informational skills, who can professionally organize and conduct classes with students on the basis of new educational experience, with the implementation of modern technologies.

Of particular importance in the process of introducing modern information and electronic technologies into the educational process is the pedagogical content of the educational material and the creation of conditions for self-study and selfdevelopment of the individual. We have in mind not only the selection of the content of the learning material, but also the structural organization of the educational material, the inclusion in the education not just of the automated training programs, but also of interactive information environments, the holistic interconnected functioning of all processes of cognition. In other words, the effectiveness and quality of training depends more on the effective organization of the learning process and the didactic quality of the materials used. For this purpose, it is the best suitable to create the Personal Teacher Website project and its corresponding training and methodological filling and practical implementation of the "private cloud» on the platform and software of Microsoft and Google, which gives Internet users the access to the server's computer resources and usage the software as an online service. Currently, the following software and services have been found and proven: Blogger, Google Classroom, Google Drive, Gmail, Google Mobile, Google Talk, Google Sites, Google Voice, Google Meet, YouTube and more.

The peculiarity of the training of the future teacher of mathematics, computer science and physics is that the modern student, constantly being in a fast-changing information society, is able to independently receive information from electronic resources. However, there is a great need to teach him not only to search for the necessary information quickly, but also to process, assimilate and use it for a better understanding of the educational material in mathematical disciplines. Willingness to work effectively in problem situations, the ability to plan their own educational and cognitive activities and evaluate the results of their work, the ability to organize personal educational space, initiative, mobility and creativity in matters of current trends in the development of mathematics, computer science and physics contribute to the competence of the teacher's profession.

Therefore, we see, that it is effective to use in the educational process of pedagogical higher education institutions the electronic training methodological complex, which operates for 6 years in the form of a personal site of teachers freely available for anyone interested in geometry (https://sites.google.com/site/geometryvspu).

Independent work of students develops the skills of researching information, learning and learning new concepts, translating the studied theoretical concepts into practical developments. Recently, the percentage of educational material and assignments for self-study by students is increasing. With the increasing amount of information being studied by students and the development of mobile communications, there is a need for remote information dissemination and student performance monitoring. That is, there is a need to create a virtual learning environment with remote access for the exchange of information between teacher and students.

Currently, Web portals are being actively developed and used in modern higher education institutions. The factor that determines their successful application is the work of teachers on electronic scientific and methodological support.

When organizing a learning process at a virtual university, it is important that the virtual team is united by a common task and interacting through information and communication technologies. Such a team can include teachers, students interacting within a virtual educational environment. In this case, virtual learning is the process and result of communication of participants of the educational process in the virtual environment (Kademiya, 2016).

A feature of Web portals is that they are usually built in the University Web site (Figure 1).

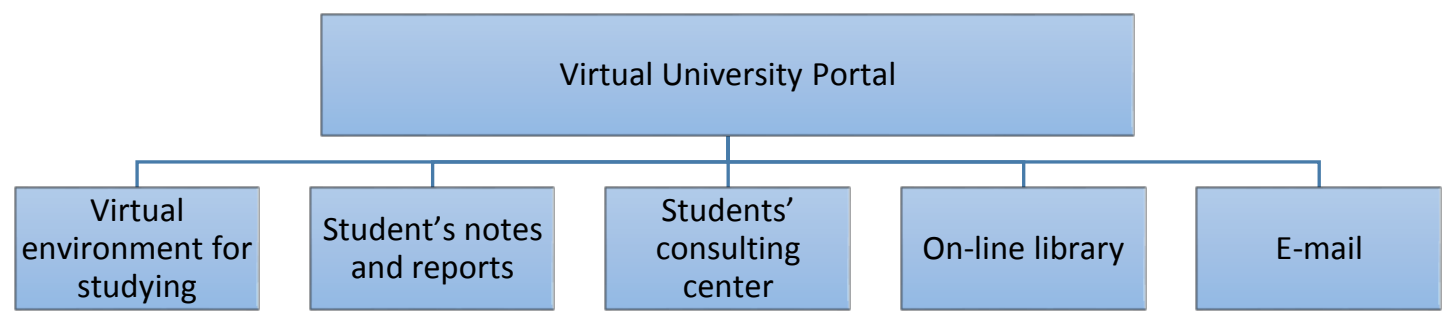

Figure 1. The structure of pedagogical university's virtual portal (made by the authors)

Each teacher and each student has access to a personal Web-cabinet. A necessary part of the educational process of the modern university is the student's Web-cabinet, which provides information about the courses they attend, the schedule of classes, access to lecture materials, controls the timing of practical and independent assignments. Typically, the Web cabinet gives you the ability to get assignments for self-study and to download the results for electronic verification. This way of working develops students' independence and responsibility for the learning process.

One of the key points in the development of the World Wide Web is the development of a virtual university - the process of creating a Web site or Web application. The term includes the development of e-commerce applications, Web design, clientside and server-side web programming, and Web server configuration. The main stages of Web development are:

- designing a website or web application;

- creating page layouts;

- filling: 
- maintenance of a working site or its software base;

- further promotion of the site on the network and raising its ranking.

Let's look at and compare the existing technologies for creating sites. Websites are divided into three groups:

- static web sites that present text, image or video information to the user without the ability to interact with the site in any way;

- interactive Web sites that allow the user to interact with the site to change the presentation or collection of site information without further downloading data from the Web server;

- Web applications that allow the dynamic content of a site to be generated based on a user's request or identification.

Web portals are the complex web applications that change their structure and content depending on the user's identity. The appearance of the site will depend on who came to the site: student or teacher, student of which specialty and course, student's teaching method, etc. Web applications are made up of two mandatory parts: the frontend and the backend. These two components of the interaction are the dynamic Web applications: frontend is the part that the user sees. It represents the site interface for user interaction; backend is a data source and software modules that process user requests.

The technologies used to create the frontend include all technologies of static and interactive Web sites such as HTML, CSS, XML, JavaScript, VBScript, JScript and others (Semenets\&Moroz, 2018). Backend databases and high-level software platforms are used to develop the backend. Databases for Web applications most often use MySQL, Oracle or MS SQL server. There is a great variety of software platforms: ASP.Net Framework, PHP, Joomla!, Ruby-on-Rails, Drupal, Java and many more. The choice of technologies for creating a web portal is based on its exact specifications.

\section{DISCUSSION}

Many universities in the world have already created or are creating a web portal to share information. Examples of university's Web portals are the University of London (UK) student portal (https://my.london.ac.uk/, 2020), the Michigan Virtual University (USA) (https://michiganvirtual.org, 2020), the Chartered Accountants of India (India) online portal (https://www.icaionlineregistration.org/, 2020), student training portal Australian Institute of Business (Australia) (https://www.aib.edu.au/students/online-learning/, 2020), self-service portal EDP University of Puerto Rico (Puerto Rico) (https://myportal.edpuniversity.edu/, 2020), Mount Kenya University (Kenya) student online portal (https://studentportal.mku.ac.ke/, 2020), National University virtual learning environment Lviv Polytechnic (Ukraine) (http://Ip.edu.ua/virtualne-navchalne-seredovyshche, 2020) and others. Figure 2 shows the interfaces of these network resources.

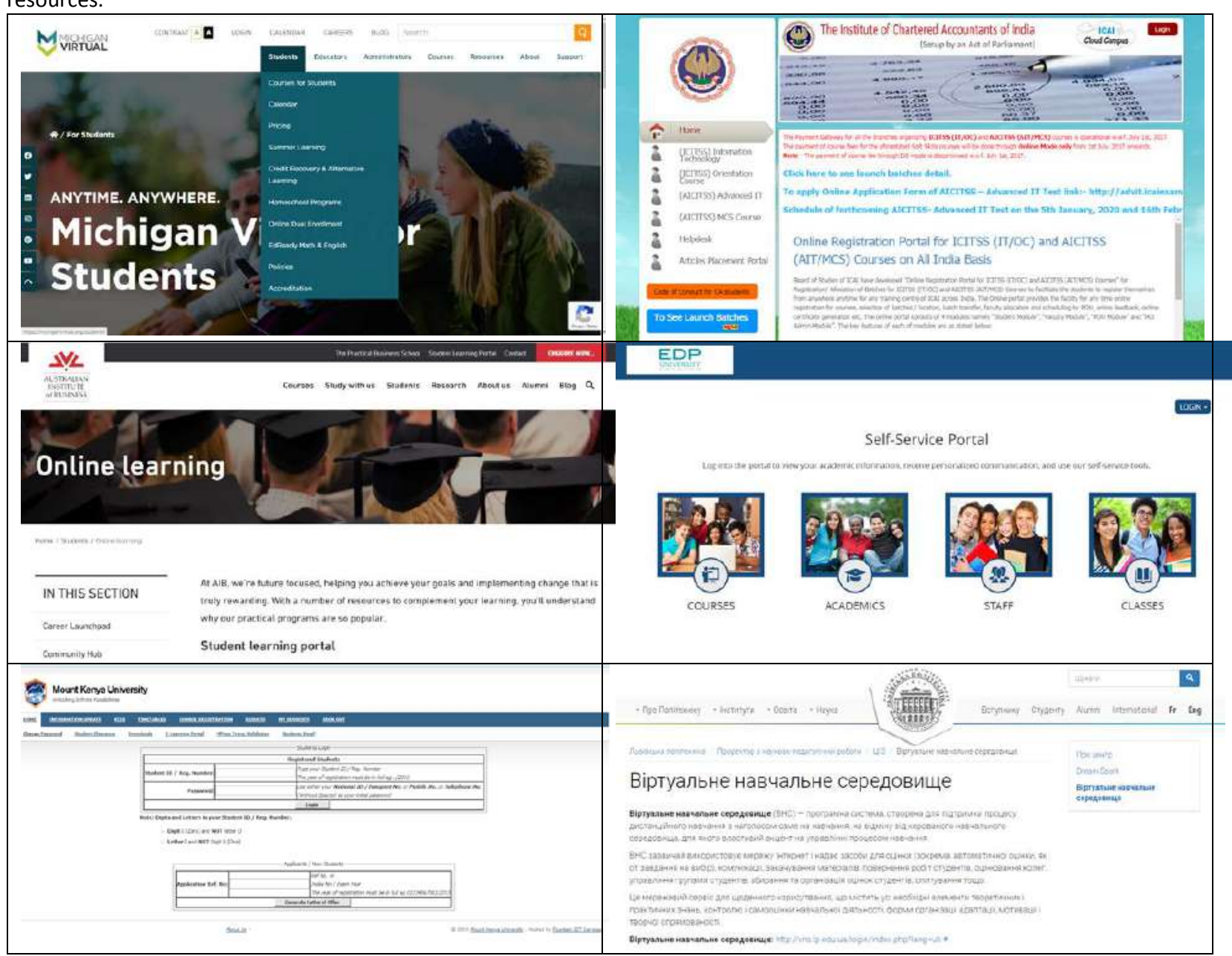

Figure 2. Interfaces of universities' Web-portals

The successful usage of the virtual learning environment implies the need for students to acquire appropriate knowledge and skills, in particular: 
- ability to work independently with various information sources and Internet resources (search, perception, understanding, selection, analysis, processing, organization and presentation, storage and transmission of information);

- knowledge of technologies of work with general-purpose software (modern packages of mathematical programs; systems of processing of text, tabular and graphic information; databases, online programs for presentations; electronic textbooks and manuals; electronic libraries, etc.);

- knowledge of algorithms, methods, techniques for solving mathematical problems efficiently with the help of a computer (mastering algorithmic skills, understanding the computer as a universal performer of mathematical problems);

- ability to use electronic communications (knowledge of ways to transmit information over distance, use of e-mail, operationing of computer networks, etc.).

These knowledge and skills are important not only in the professional training of future teachers of mathematics, computer science and physics, but also to ensure the availability and continuity of education throughout life.

\section{CONCLUSIONS AND PROSPECTS FOR FURTHER RESEARCH}

The analysis of the modern informational educational space and the experience of using the above site to provide elearning testifies to the urgent need and relevance of creating and using virtual learning environments not only in geometry or other mathematical disciplines, but also in general educational program for students of physical and mathematical specialties who are trained in pedagogical higher education institutions. This kind of electronic educational-methodical complex transforms the activity and communication of teachers and students, changes the methodical systems of study of educational disciplines and promotes: optimization of educational load of students; mastering the main content of the discipline; objectivity in assessing knowledge and skills; forming in them the ability to carry out self-education in advance prepared plan, based on certain conditions; developing the ability to exercise self-control and self-assessment of learning activities. However, it is not necessary to exaggerate the capabilities of Web portals, because the transfer of information does not ensure the transfer of knowledge, culture, thinking and is only an important educational tool. This, in turn, requires the correct selection of the content of the training in accordance with the didactic properties and capabilities of the information technology training tools; prediction of the possible impact of information technology training on the way of thinking and behavior of participants in the educational process, etc. This is what we refer to further areas of study.

\section{References}

1. Hurevych, R.S., Koziar, M.M., Kademiia, M.Yu. \& Sevchenko, L.S. (2015). Innovatsiini tekhnolohii navchannia v umovakh informatyzatsii osvity : monohrafiia [Innovative learning technologies in the conditions of informatizational education]. Lviv : LSU BZHD [in Ukrainian].

2. Hurevych, R.S., Kademiia, M.Yu. \& Koziar, M.M. (2012). Informatsiino-komunikatsiini tekhnolohii v profesiinii osviti maibutnikh fakhivtsiv [Information and communication technologies in professional education of future specialists]. Lviv : SPOLOM [in Ukrainian].

3. Lazarenko, N.I., Kolomiiets, A.M. \& Klymenko, A.O. (2017). Symbioz metodolohichnykh pidkhodiv do rozvytku osvity v umovakh informatsiinoho suspilstva [Symbiosis of methodological approaches to the development of education in the information society]. Nauka i osvita - Science and education, 4, 107-112 [in Ukrainian].

4. Velychko, S.P. (2008). Suchasne osvitnie seredovyshche ta ioho vplyv na pryrodnycho-matematychnu i tekhnichnu osvitu [Modern educational environment and its impact on science and mathematics and technical education]. Naukovi zapysky. Pedahohichni zapysky - Scientific notes. Pedagogical notes, (77), part 2, 3-8 [in Ukrainian].

5. Kovtoniuk, M.M. \& Didovyk, M.V. (2018). Formuvannia onnovatsiinoho seredovyshcha maibutnikh ychyteliv matematyky ta fizyky [Formation of an innovative environment for future teachers of mathematics and physics]. Suchasni informatsiini tekhnolohii ta innovatsiini metodyky navchannia u pidhotovtsi fakhivtsiv: metodolohiia, teoriia, dosvid, problemy - Modern information technologies and innovative education methods in specialist's training: methodology, theory, experience, problems, (50), 293-298 [in Ukrainian].

6. Tiutiun, L.A. \& Soia, O.M. (2018). Zabezpechennia E-learning za dopomohoiu personalnoho saitu bykladacha [Providing elearning through the teacher's personal website]. Proceedings of the 2nd International Scientific and Practical Conference: Suchasni informatsiini tekhnolohii ta innovatsiini metodyky navchannia: dosvid, tendentsii, perspektyvy - Modern information technologies and innovative education methods: experience, trends, perspectives. (pp. 247-249), Ternopil [in Ukrainian].

7. Tiutiun, L.A. \& Soia, O.M. (2018). Vykorystannia paketiv prykladnykh prohram u protsesi profisiinoi pidhotovky studentiv fizyko-matematychnykh spetsialnostei [The use of application packages in the process of professional students training of physical and mathematical specialties]. Suchasni informatsiini tekhnolohii ta innovatsiini metodyky navchannia u pidhotovtsi fakhivtsiv: metodolohiia, teoriia, dosvid, problemy - Modern information technologies and innovative education methods in specialist's training: methodology, theory, experience, problems, (52), 415-421 [in Ukrainian].

8. Kademiia, M.Yu. (2016). Orhanizatsiia navchalnoho protsesu u virtualnomu universyteti [Organization of the educational process in a virtual university]. Suchasni informatsiini tekhnolohii ta innovatsiini metodyky navchannia u pidhotovtsi fakhivtsiv: metodolohiia, teoriia, dosvid, problemy - Modern information technologies and innovative education methods in specialist's training: methodology, theory, experience, problems, (46), 191-197 [in Ukrainian].

9. Semenets, D.A. \& Moroz, D.S. (2018). Prohramuvannia saitiv. Bazy danykh dlia saitiv. Yak zakhystyty sait vid zlomu? [Website programming. Databases for sites. How to protect the site from hacking?]. Matematyka ta informatyka navkolo nas - Mathematics and computer science around us, (2), 152-158. [in Ukrainian]. 


\section{ВИКОРИСТАННЯ ЕЛЕКТРОННОГО ОСВІТНЬОГО КОНТЕНТУ В ЗАКЛАДАХ ВИЩОЇ ОСВІТИ}

\section{Д.А. Семенець, О.М. Соя, Л.А. Тютюн}

Анотація.

Вінницький державний педагогічний університет імені Михайла Кочюбинського, україна

Формулювання проблеми. У сучасних умовах актуальність дослідження щодо доцільності та методологічних засад інтегрованого використання електронного освітнього контенту в закладах вищої освіти та виявлення особливостей його функціонування незаперечна. Інновачійний підхід до впровадження цифрових технологій навчання суттєво змінив освітній простір і дозволяє вирішувати низку важливих дидактичних проблем. Зокрема, функціонування віртуальних навчальних середовищ забезпечує широкі можливості щодо мобільності студентів у навчанні, враховує їхні особисті потреби і вподобання, дозволяє студенту обрати зручний час і місце для навчання, працювати за індивідуальним графіком, планувати розпорядок роботи, будувати власну освітню траєкторію тощо.

Матеріали і методи. Ми проаналізували дослідження сучасних науковців і методистів, здійснили моніторинг Веб сайтів закордонних та українських університетів, використали власний педагогічний досвід.

Результати. Обгрунтовано, що створення та використання віртуальних навчальних середовищ у закладах вищої освіти забезпечує реалізацію принципів індивідуалізації, свідомості й активності, візуалізації, доступності навчання; набуття компетенцій щодо використання програмних засобів для вирішення професійних задач. Наведено приклад створення проекту «Персональний сайт викладача» з відповідним навчально-методичним наповненням. Проведено дослідження сучасних актуальних технологій, які дозволяють створювати Web-сайти та Web-портали, розглянуто засоби розробки Web-сайтів та класифіковано їх за складністю. Показано, що веб-кабінети студентів створюються з використанням відомих баз даних та програмних платформ високого рівня.

Висновки. Не варто перебільшувати можливості Web-порталів, адже їх створення вимагає правильного відбору змісту навчання відповідно до дидактичних властивостей і можливостей засобів цифрових технологій навчання, прогнозу можливого впливу на характер мислення і поведінки учасників освітнього процесу тощо.

Ключові слова: віртуальне навчальне середовище, інформаційно-комунікаційні технології, електронне навчання, заклади вищої освіти, підготовка фахівиів, Web-сайт, Web-портал. 